\title{
El grand tour: el signo de educación de un gentleman
}

\author{
Katharina Lau, M.A. \\ Ruprecht-Karls-Universität, Heidelberg
}

Artículo recibido: 27-3-2012 / Aceptado: 8-6-2012

Resumen: El pintor italiano Pompeo Girolamo Batoni (1708 - 1787) se estableció firmemente como el pintor del Grand Tour. Su abundante producción de retratos presenta en su mayoría a jóvenes gentlemen que exhiben la energía vibrante de su nación. La posesión de un retrato de Batoni no sólo indicaba que el retratado era un hombre de gusto, sino que también su imagen se convertía en un recuerdo de valor inapreciable que demostraba que había completado con éxito el Grand Tour. Aunque los retratos puedan parecer similares, este artículo examina las variaciones distintivas que resultan de los gustos de los clientes y sus preferencias individuales. En conjunto, estas imágenes presentan un retrato propio, el retrato de los británicos en el extranjero durante la era georgiana.

Palabras clave: Batoni, retrato inglés, Grand Tour, gentleman, siglo XVIII, Inglaterra.

AbStRACT: The Italian painter Pompeo Girolamo Batoni (1708-1787) established himself firmly as the Grand Tour painter. His brisk portrait production presented mostly young English gentlemen exuding the vibrant power of their nation. To own a Batoni portrait not only proved the subject a man of taste, his picture became an invaluable souvenir, demonstrating that he had successfully completed the Grand Tour. Although the portraits seem similar, this article examines distinctive variations resulting from the subjects' individual tastes and preferences. Collectively, these pictures present their own portrait, one of the British abroad in the Georgian era.

Key words: Batoni, English portraiture, Grand Tour, gentleman, 18th Century, England.

\section{INTRODUCTION}

From the beginning of the eighteenth century public education in Great Britain began to gain popularity. This drift away from private tutoring towards group teaching included the possibility of studying abroad with peer companions on the so called Grand Tour. Its main object was to explore the cultural and antique treasures of Continental Europe.
This journey was a very sumptuous affair undertaken initially only by the upper nobility and gentry, although later on, by the moneyed aristocratic members of the new middle class as well. ${ }^{1}$ The travellers, par-

${ }^{1}$ This paper is partly based on my M.A. thesis, Die Darstellung des Gentlemanideals in englischen Portraits der zweiten Hälfte des 18. Jahrhunderts", Magistra Arbeit, Ruprecht-Karls-Universität Heidelberg, 2009, see K. LAU, Die Darstellung des Gentlemanideals in 
ticularly the younger ones, liked the journey through Europe not just because they discovered fascinating artistic and architectural treasures but especially because they enjoyed the collective experience and personal adventure.

The Grand Tour - a long-term voyage - was almost a requirement for young men in polite British society throughout the Georgian period. It contributed to their academic education with an intense training program designed to broaden their knowledge and not just provide enjoyment and relaxation. Rémy G. Saisselin writes:

"The Grand Tour was the confirmation of the man of taste, and I use the word with its religious connotations consciously, as Italy became a place of aesthetic pilgrimage. The Grand Tour was the finishing touch of the gentleman's education. But as concerns Taste it can hardly be likened to a voyage of discovery; ... One knew what to look for, what to look at, what to admire, and what to bring back. There had been books to tell you all that; there were guides to help form your taste; there were artists to advise you ... Thus the Grand Tour was not only a school of taste, but also one of conformity." 2

Although the Grand Tourists travelled to France, Italy was their principal destination, the high point of their long continental

englischen Portraits der zweiten Hälfte des 18. Jahrhunderts, nicht veröffentlichte Magistra Arbeit, Ruprecht-KarlsUniversität Heidelberg, 2009. My special thanks go to my family.

Although the Grand Tour peaked in the second half of the eighteenth century it had roots in the Middle Ages. Medieval pilgrimages to sanctuaries, made in an era characterized by an extremely spiritual and highly religious mood, can be seen as a kind of precursor of the later Grand Tour. The pilgrims' main aim, of course, was more an expression of their piety than an effort to get in touch with different European customs and cultures as was the case with travellers in the eighteenth century. For further reading see C. HIBBERT, The Grand Tour, London, 1987.

${ }^{2}$ R. G. SAISSELIN, "The Man of Taste as Social Model, or, "Sense and Sensibility"', J.CARRÉ (ed), The Crisis of Courtesy: Studies in the Conduct-Book in Britain, 1600- 1900, Leiden, 1994, pp. 119-127, here p. 123. route. Florence, Rome, Naples and the surrounding area of Vicenza ${ }^{3}$ formed a cultural centre that came to be reflected in fashion and art. In the Italian cities the young gentlemen explored the ancient world through the first-hand study of ruins together with sculptures and paintings by Renaissance masters - Raffaello Sanzio (1483- 1520), for instance, better known as Raphael - and Michelangelo Buonarotti (1475- 1564). They also observed the new artistic movements taking place in the countries they visited.

\section{THE REPETITIVE STRUCTURE OF GRAND TOUR PORTRAITS}

The gentlemen on the tour not only studied art, they themselves became the subject of a sizable body of portraiture that memorialized them on their trip. Antiquarianism and enthusiasm for Italy dominate their portraits. Although they travelled through many provincial towns and visited a great number of impressive cities, most of their portraits depicted them in Rome, then the most important destination for British travellers on the Grand Tour.

The portraits commissioned in Rome had a more or less standard structure. Typically, they included a room decorated with antique busts accompanied by books, including travel guides and maps showing the travellers' planned itineraries. Furthermore, the portrayal of the tourists before wellknown architecture, frequently the Colosseum, formed an inherent part of this genre. The three-quarter portrait of Sir Gregory Page-Turner (fig. 1$)^{4}$ by the Italian Pompeo Girolamo Batoni (1708- 87) exemplifies this brilliantly.

\footnotetext{
${ }^{3}$ The type of Palladian villa built by the Italian Renaissance architect Andrea Palladio (1508- 80) in the region around Vicenza would strongly influence the upcoming English Palladianism. A good example of this style is the Chiswick House in London.

${ }^{4}$ POMPEO BATONI, Sir Gregory Page-Turner, 1768, Oil on canvas, 134.5 x $99.5 \mathrm{~cm}$, Manchester, Manchester Art Gallery.
} 
Turner's body posture strongly resembles that of famous antique statues - for example, the Apollo Belvedere, which repeatedly served as a model for heroic presentations of the gentlemen portrayed. See, for instance, Sir Joshua Reynolds' (1723- 92) Captain the Honourable August Keppel ${ }^{5}$.

Portrait painters frequently turned to antiquity, not just for background, but for the poses of their subjects, especially the elder English Gentlemen, showing them, for example, as ancient Roman orators, philosophers or senators. The engraving by Simon Gribelin (1661- 1733) after John Closterman (1660-1711) of Anthony Ashley-Cooper, 3rd Earl of Shaftesbury (fig. 2) ${ }^{6}$ provides a good example. Let us examine it in more detail.

Closterman's composition demonstrates clearly the harking to ancient times in the Grand Tour portraits. ${ }^{7}$ He portrays the Earl as a philosopher from antiquity dressed in a Roman toga. He stands in a room modelled after antique architecture, which adds to the ancient aura of this painting. Shaftesbury looks directly at the observer and holds

5 SIR JOSHUA REYNOLDS, Captain the Honourable August Keppel, 1752- 53, Oil on canvas, 239 x $147.5 \mathrm{~cm}$, Greenwich, London, National Maritime Museum.

${ }^{6}$ SIMON GRIBELIN AFTER JOHN CLOSTERMAN, Anthony Ashley-Cooper 3rd Earl of Shaftesbury, 1723, Line engraving on paper, 179 × $98 \mathrm{~mm}$, London, National Portrait Gallery. Further readings on Shaftesbury and his influence on Early Georgian Britain see L. E. KLEIN, Shaftesbury and the Culture of Politeness: Moral Discourse and Cultural Politics in Early Eighteenth-Century England, Cambridge, 1994 and L. E. KLEIN, “Cooper, Anthony Ashley, third earl of Shaftesbury (1671-1713)", Oxford Dictionary of National Biography, Oxford, 2004.

According to the Oxford Dictionary of National Biography, the portrait by Closterman in St Giles House, Wimborne St Giles, Dorset, which was the basis for the Gribelin's engraving, was painted circa 1700-1701, see Klein, 2004. Essentially the portrait is dated to 1702, as Nicholas Ashley-Cooper, $12^{\text {th }}$ Earl of Shaftesbury wrote me in a private correspondence on March 28 ${ }^{\text {th }}, 2011$.

${ }^{7}$ See D. MANNINGS, "Shaftesbury, Reynolds and the Recovery of Portrait-Painting in Eighteenth-Century England. In Memory of Dr. Judith Hook", Zeitschrift für Kunstgeschichte 48, $\mathrm{n}^{\circ} .3,1985$, pp. 319-328, here p. 320. a book against his breast with his right hand. He leans on a pedestal where weighty tomes by Plato and Xenophon are displayed. ${ }^{8}$ Beside these antique elements, however, we also find evidence of contemporary taste of the period. For example, the Earl wears an Allonge periwig following the hair-style in fashion from the late seventeenth through the first half of the eighteenth century. A gathered curtain is draped baldachin-like in the upper half of the picture. ${ }^{9}$ The view through the arch in the background opens to a prospect of a formal Baroque garden à la française. ${ }^{10}$

This portrait shows a perfect synthesis of two different époques widely separated in time. On the one hand, antiquity is represented through architecture and dress; and on the other, the Frenchified taste of the Baroque period is demonstrated by the geometrical garden, the periwig, and the Earl's display of shoes with heels, which only the aristocracy were permitted to wear. ${ }^{11}$

${ }^{8}$ Ibidem, p. 321.

${ }^{9}$ Here, the preference for French taste is very obvious. This picture can be compared to several aristocratic portraits painted in France in this period. The most famous and, roughly speaking, a precursor, is HYACINTHE RIGAUD'S portrait of Louis XIV (1701, Oil on canvas, 277 x 194 cm, Paris, Musée du Louvre). Here, we also have the richly curled Allonge perruque - as it is called in French - together with the proud and upright posture of the subject and a draped curtain framing the picture. Further Philip Mansel formulates it accurately that "France remained the model of fashion and magnificence for the court of England.", P. MANSEL, Dressed to Rule: Royal and Court Costume from Louis XIV to Elisabeth II, New Haven, 2005, p. 14. Linda Colley likewise confirms that "in all cases the original was the same: the court dress of Louis XIV's Versailles.", L. COLLEY, Britons: Forging the Nation 1707- 1837, New Haven, 2009, p. 168.

${ }^{10}$ Here again, following the taste of Louis XIV (1638- 1715) in Versailles.

${ }^{11}$ Mansel talks in detail about the meaning of dress and shoes - especially the significance of red heels - in the High Baroque period, highlighting the French court. For further reading see P. MANSEL, 2005, pp. 1- 17, on shoes especially p. 15. 
As we have seen, the whole composition is cast in the spirit and tradition of antiquity, a style that will continue in Grand Tour portraits throughout the second half of the eighteenth century, as this paper will demonstrate. Batoni, a master of this emphasis on antiquity, emerges as the most important painter of the large circle of Grand Tourists. Furthermore, his continuous production of portraits affords us an easy opportunity to examine selected pictures, as we shall in the following analysis.

\section{YOUNG ARISTOCRATS MARCHING TO THE CONTINENT}

Initially, I would like to discuss Batoni's full-figure portrait of Sackville Tufton, 8th Earl of Thanet (fig. 3) ${ }^{12}$ a young aristocratic traveller. It shows a very typical presentation of the model in an antique room. The view through a round arch window opens a prospect to the outside. Here again, the composition links the old world with the new. The column in the back reminds us that antiquity has been combined with the Baroque, which is exemplified by the cushioned chair standing to the left of the young Earl. Through Thanet's casual posture, especially his crosslegged stance, Batoni gives the portrait a certain elegance and nonchalance.

Thanet leans with his left elbow on a pedestal decorated with a bust of Minerva, the Roman goddess of wisdom, plus a globe, books, and writing quills. These props were not selected by chance. The bust - that looks in the same direction as Thanet - can be considered a symbol of the knowledge the young Thanet will acquire on his travels through the continent. Furthermore, he may well write down his experiences in the book which is also displayed on his side. He holds his right hand on his hip, and in his left hand he has a folded piece of paper. With a slightly turned head he looks to the left, at something far out of the picture. Perhaps he

12 POMPEO BATONI, Sackville Tufton, 8th Earl of Thanet, 1753- 54, Oil on canvas, 233.7 x $147.3 \mathrm{~cm}$, Private Collection. is taking a few minutes to review his impressions of the Grand Tour. His two dogs in the right corner accompany him and can hardly wait to continue the journey.

Now let us cast a glance at Thanet's dress. Here Batoni follows the Van Dyck manner of the seventeenth century. He puts his model in the so-called Van Dyck costume with a white lace-collar and grey-brown silk suit. ${ }^{13}$ Batoni knew the portraits by the Flemish painter Sir Anthony Van Dyck (15991641) and frequently presented this outfit in his pictures. "The wearing of this costume by men and women was quite common among the fashionable elite as a masquerade dress in the $1740 \mathrm{~s}^{\prime \prime}{ }^{14}$ Batoni's portrait of a successful farmer and rich landowner Thomas William Coke, later 1st Earl of Leicester (fig. 4$)^{15}$ demonstrates this point. In it Batoni attaches great importance to the fashionable clothes in contrast to the dark and rather sober costume of Thanet (fig. 3). Batoni dresses Coke in a stylish suit after the current Italian taste. His set of clothes resembles a modified Van Dyck costume, with the whole outfit, including the lace-collar, now made of silver silk. A pink bow adorns the collar, and Coke's left shoulder is covered with a pink, ermine-trimmed cape. Finally, the pink and white feathered hat, which Coke holds in his right hand, perfects the two-coloured ensemble. Compared to Thanet again, Coke is portrayed as a very trendy and rich man who displays his wealth through this painting, which is rather unusual for the generally modest English gentlemen.

${ }^{13}$ Children and young boys were usually dressed and portrayed in the Van Dyck costume. A wonderful example is THOMAS GAINSBOROUGH'S (1727- 88), Jonathan Buttal: The Blue Boy, around 1770, Oil on canvas, 179 x 123 cm, San Marino, USA, Huntington Library.

${ }^{14}$ E. PETERS BOWRON / P. B. KERBER (eds.), "British Patrons and the Grand Tour", Pompeo Batoni: Prince of Painters in Eighteenth-Century Rome, New Haven, 2007, pp. 37- 87, p. 55.

${ }_{15}$ POMPEO BATONI, Thomas William Coke, later 1st Earl of Leicester, 1773- 74, Oil on canvas, $245.8 \times 170.3$ $\mathrm{cm}$, Norfolk, The Earl of Leicester and the Trustees of the Holkham Estate. 
Analysing further the attitude shown in this painting, we see that Batoni abandons the so called "cross-legged pose"16 often used in male portraiture to show a kind of nonchalance, as demonstrated in the portrait of Thanet. Instead, he varies the posture, showing Coke with his feet fixed on the ground but not seeming stiff in any way. The slight angle of his hip lends gracefulness to his whole appearance. ${ }^{17}$ Behind Coke we see the Sleeping Ariadne. ${ }^{18}$

Generally speaking, the whole composition presents a self-confident gentleman whose "handsome and fashionable appearance"19 was certainly noticed by other travellers.

\section{GENTLEMEN ABROAD - CRITICAL VOICES AT HOME}

Thomas William Coke was not an exception amongst the English tourists in his way of dressing. We have already mentioned Sir Gregory (fig.1) with his rich, red, embroidered three-piece suit - a further example of the numerous aristocratic and wealthy young men depicted as modern, fashionable, and extravagant sightseers. ${ }^{20}$ "What is the consequence?"21 asks the Scottish author Tobias George Smollett (1721- 71) in 55.

${ }^{16}$ E. PETERS BOWRON / P. B. KERBER, op. cit., p.

${ }^{17}$ Ibidem.

${ }^{18}$ It is said that the sculpture of Ariadne in this portrait was given the features of Coke's young wife, see E. PETERS BOWRON, Pompeo Batoni (1708-87) and his British Patrons, London, 1982, p. 65.

${ }^{19}$ E. PETERS BOWRON / P. B. KERBER, op. cit., p. 55.

${ }^{20}$ More on costume see in: A. RIBEIRO, "Batoni's use of costume", E. PETERS BOWRON, Pompeo Batoni (1708-87) and his British Patrons, London, 1982, p. 21.

${ }^{21}$ T. G. SMOLLETT, Travels through France and Italy. Containing Observations on Character, Customs, Religion, Government, Police, Commerce, Arts, and Antiquities. With a Particular Description of the Town, Territory, and Climate of Nice: to Which is Added, a Register of the Weather, Kept During a Residence of Eighteen Months in that City, Vol. 1, London, 1766, p. 96. his Travels through France and Italy (1766), and he responds to his question as follows:

"When an Englishman comes to Paris, he cannot appear until he has undergone a total metamorphosis. At his first arrival he finds it necessary to send for the taylor, peruquier, hatter, shoemaker, and every other tradesman concerned in the equipment of the human body. He must even change his buckles, and the form of his ruffles; and though at the risque of his life, suit his cloaths to the mode of the season." 22

Apart from broadening the young gentlemen's educational horizons, the development of a keen sense of taste - as demonstrated above - was one of the objects of their long journey. The style changes they made on the Grand Tour seem remarkable when we remember traditional English portraiture with its more muted colours and generally sober and inconspicuously clothed eighteenth-century English gentlemen. The portraits painted by Thomas Gainsborough (1727- 1788) provide examples. Yet suddenly, on the Tour, we encounter Englishmen wearing colourful silk coats and richly embroidered vests, easily adopting the Continental fashions of Italy and France, ${ }^{23}$ as Smollett observed.

Why this metamorphosis? It happened because the portrait clients wanted to be seen in current Continental fashions. Philip Dormer Stanhope, Earl of Chesterfield, for example, wrote to his son saying that a gentleman should dress "as well, and in the same manner, as the people of sense and fashion of the place where he is. ${ }^{24}$ And Smollett again reported on the situation in 1766:

${ }^{22}$ T. G. SMOLLETT, op. cit., p. 97.

${ }^{23}$ See E. PETERS BOWRON / P. B. KERBER, 2007, p. 38.

24 L. CHESTERFIELD, Lord Chesterfield's letters, Oxford, 2008, p. 128. Further readings about the courtesy and conduct-books see J. CARRÉ (ed), The Crisis of Courtesy: Studies in the Conduct-Book in Britain, 1600- 1900, Leiden, 1994.

on Chesterfield's letters particularly see G. LAMOINE, "Lord Chesterfield's Letters as Conduct- 
"The French, however, with all their absurdities, preserve a certain ascendancy over us, which is very disgraceful to our nation; and this appears in nothing more than in the article of dress. We are contented to be thought their apes in fashion; but, in fact, we are slaves to their tailors, mantua-makers, barbers, and other tradesmen." 25

The accuracy of this statement has already been proven by the portraits discussed above (fig. 1, 4), produced while the subjects were on the Grand Tour. But now let us look at things from a different angle. Although many of the gentlemen abroad courteously assumed local customs and were often "decidedly unpatriotic"26 in adapting to foreign trendiness, we must take into consideration that "French fashions appealed ... primarily because their elegance, cost and complete impracticality advertised the gentle status of the wearer" 27 and furthermore there was also a practical reason for some of this behaviour. English wool was too thick and warm for the mild Mediterranean climate. Consequently, the English gentlemen changed their woollen clothes to new ones made of light Continental fabrics more suitable for the warm local temperatures.

Back home it became common to behave and dress almost slavishly in a French style and to absorb flowery foreign phrases into English conversations. However, this behaviour, with the airy manner that often accompanied it, came to be frowned upon towards the end of the eighteenth century. The Grand Tour itself began to be viewed increasingly critically ${ }^{28}$ as we can see, for instance, in Henry Mackenzie's Man of Feeling:

Books", in: J.CARRÉ (ed), The Crisis of Courtesy: Studies in the Conduct-Book in Britain, 1600-1900, Leiden, 1994, pp. 105-117.

${ }^{25}$ T. G. SMOLLETT, op. cit., p. 95.

${ }^{26}$ J. RIDING, Mid-Georgian Britain: 1740-69, Oxford, 2010, p. 45.

${ }^{27}$ L. COLLEY, op. cit., p. 168.

${ }^{28}$ Smollett had already called the English abroad "apes in fashion", T. G. SMOLLETT, 1766, p. 95.
"Indeed, the education of your youth is every way preposterous: you waste at school years in improving talents, without having ever spent an hour in discovering them; one promiscuous line of instruction is followed, without regard to genius, capacity or probable situation in the commonwealth. From this menagerie of the pedagogue, a raw unprincipled boy is turned loose upon the world to travel; without any ideas but those of improving his dress at Paris, or starting into taste by gazing on some paintings at Rome. Ask him of the manners of the people, and he will tell you, That the skirt is worn much shorter in France, and that every body eats macaroni in Italy. When he returns home, he buys a seat in parliament, and studies the constitution at Arthur's." 29

THE GRAND TOUR: GETTING FURTHER BY FURTHER EDUCATION

A study of politics and social graces, including good manners, a careful review of foreign fashion, and, last but not least, intense discussions about Continental artthis was the canon of the Grand Tour. The English aristocrat practised it by submitting the artefacts he encountered to careful examination, comparing them with other objects of art, and discussing his discoveries with his Tour colleagues. The most important consequence of this popular leisure activity was the beginning of so-called connoisseurshi $^{30}$, which was accompanied by collecting artefacts. This process was crucial for the development of a gentleman's ideals and taste. Part of his experience of the tour consisted of bringing masterpieces of foreign art to the British Isles, installing them in his mansion, and thereby demonstrating his wealth, knowledge, and refined sense of style which

${ }^{29}$ H. MACKENZIE, The Man of Feeling, London, 1771, pp. 76- 77.

30 See I. PEARS, The Discovery of Painting. The Growth of Interest in the Arts in England, 1680-1768, New Haven, 1988, pp. 181- 206. 
in turn led to the establishment of numerous famous collections. ${ }^{31}$

The mass of customised portraits served as mementoes of the Grand Tour and were - in addition to shipped artefacts and cast copies of antique sculptures - very popular souvenirs of the gentleman's long journey. With his portrait, the tourist not only demonstrated that he had successfully completed a kind of educational training but had gained insights into Continental art and architecture, as depicted in the picture of himself that he brought home.

Especially in late Georgian Britain, stories about the countries visited and vivid exchanges about past travels were very popular subjects of discussion. As was mentioned above, the influence of their experiences and the discussions about them brought about the formation of the so-called connoisseurs, who met, for example, in the Society of Dilettanti, established in $1734 .^{32}$ Dilettanti were important promoters and sponsors of the arts. The society members wrote down and published their experiences and adventures in foreign countries to preserve them for the future, providing examples of past cultural life and present new tendencies. Batoni's Thomas Dundas, later $1^{\text {st }}$ Baron Dundas (fig. 5) ${ }^{33}$ is a typical portrayal of one of the Dilettanti. Dundas stands with his legs

31 Bärbel Küster characterizes these trips as "Einkaufstouren", which is the equivalent of "shopping trips" in English (my translation). See B. KÜSTER, "Funktion und Öffentlichkeitscharakter der KunstSammlung in England im 18. Jahrhundert", A. W. VETTER (ed.), Museen und fürstliche Sammlungen im 18. Jahrhundert, Braunschweig, 2007, pp. 84- 93, here p. 84.

${ }^{32}$ The word Dilettanti had no negative connotation as it has today. The members of the Society of Dilettanti, who were obliged to make the Grand Tour, had erudite conversations about art and culture in an atmosphere of conviviality. Passing time with club members was a leisure activity for them. For further reading see B. REDFORD, Dilettanti: The Antic and the Antique in Eighteenth-Century England, Los Angeles, 2008.

33 POMPEO BATONI, Thomas Dundas, later 1st Baron Dundas, 1764, Oil on canvas, 298 x $196.8 \mathrm{~cm}$, Property of Marquess of Zetland. crossed, almost dancing, in an antique room surrounded by columns. He wears a red, three piece suit, "à la marinière" a hiking stick and a black tricorn hat in his right hand. He is encircled by the sculptures of Apollo of Belvedere, the Laocoön Group and the Antinoos of Belvedere, all arranged in a virtual exhibit in the background, almost resembling a market hall selling works of art. To Dundas' left we see again the Sleeping Ariadne, as in the portrait of Coke (fig. 4). On closer inspection we discover that the statue's pedestal forms a fountain. ${ }^{35}$ Surely, it is not for nothing that Dundas points his hand to it: Is he about to buy this antique marmoreal beauty to bring her to Britain and thus demonstrate his refined taste to polite society? It is quite obvious that "one of the attractions ... in the Grand Tour was to see art ... and preferably to buy some of it"36 and along with that, to show "the depth of one's pocket." ${ }^{37}$ Whatever his plans, he seems clearly to be the master of the situation who knows what he wants.

In the picture Dundas displays some of the most famous antique monuments that a well-educated English gentleman and member of the Society of Dilettanti, which Dundas definitely was, ${ }^{38}$ should have seriously studied. He provides the spectator with an impression of old Rome through the antique statues while the new Rome is represented by the fountain. Its style is strongly reminiscent of Roman Baroque fountains the Grand Tourist must have seen and been strongly impressed by. ${ }^{39}$

\footnotetext{
${ }^{34}$ E. PETERS BOWRON, 1982, p. 51.

${ }^{35}$ Ibidem.

${ }^{36}$ L. COLLEY, 2009, p. 168.

${ }^{37}$ Ibidem, p. 169.

${ }^{38}$ See E. PETERS BOWRON, op. cit., p. 51.

${ }^{39}$ Ibidem .
} 


\section{THE ELDER GENERATION GOES TO THE CONTINENT}

The majority of the young gentlemen (and most were young) not only absorbed foreign cultures during their tour, but continued many new customs back in England. Nevertheless, there were exceptions, especially among the older generation. The more elderly gentlemen clearly preferred to be portrayed in their traditional style and loyal to their homeland rather than as imitators of foreign fashions like their younger countrymen.

Batoni's full figure portrait of Colonel the Honorable William Gordon (fig. 6) $)^{40}$ is an example of the national pride sometimes shown by the subjects. Gordon stands in the middle of architectural ruins with the Colosseum in the background to his left. He supports himself with his sword, which he holds in his right hand.

The Colonel wears a uniform, and his full attire is eye-catching. The difference between this and the other portraits discussed in this study is striking. Batoni replaced the usual breeches with a kilt and stockings, both in the brightly striped tartan of the Huntly Clan. ${ }^{41}$ Gordon's cloak falls down his left shoulder in the style of an antique toga. ${ }^{42}$ The viewer sees a man full of energy and self confidence. His chosen dress clearly advertises his Scottish identity, and by wearing Highland attire rather than the clothes usually worn by the Grand Tourists, he demonstrates that he is a man with an independent spirit. His prominent bearing is tense and concentrated and demonstrates pride and self-assurance. His sword and uniform show him to be a man with military author-

${ }^{40}$ POMPEO BATONI, Colonel the Honorable William Gordon, 1765- 66, Oil on canvas, 259 x $187.5 \mathrm{~cm}$, Aberdeenshire, The National Trust for Scotland, Fyvie Castle.

${ }^{41}$ See E. PETERS BOWRON / P. B. KERBER, op. cit., p. 66.

${ }^{42}$ See E. PETERS BOWRON, op. cit., p. 54. For comparison see (fig. 2). ity, which he celebrates proudly in the portrait. The Scottish Colonel is ready to conquer the Eternal City on his personal Grand Tour, and not by chance does he look left into the future fixing his gaze on the globe that the "statue of the goddess Roma"43 stretches towards him with her right hand.

In some cases older gentlemen went on the Grand Tour for health and recreational reasons, and, whereas younger men made very long trips through Europe, the Continental visits of adult English gentlemen were rather short. The portrait of Sir Humphry Morice (fig. 7) ${ }^{44}$ provides an example of an adult gentleman on tour. ${ }^{45}$

In Batoni's horizontal portrait Sir Morice sits on a stone surrounded by green trees and his three dogs. He looks directly at the spectator. His hair is not powdered. He loosely holds his right hand on his chest while his left hand embraces a dog that looks up at his master. Sir Morice is dressed in a grey three-piece-suit. He has sat down to relax from hunting; resting his gun on his right side. His game-a hare and birds - in the front of the picture demonstrate his hunting ability.

The picture of Morice gives us an example of a Grand Tour portrait painted in a rustic setting rather than amongst ancient or Baroque gardens or architecture, like most of his younger contemporaries. Had this picture been painted on his property in England, fences would probably be seen, demonstrating the size of his estate. But here, Batoni demonstrates the remote nature of the setting by placing his model far from human creations, exemplified by the "Torre dei Venti,"46 in the distant background. 66.

${ }^{43}$ E. PETERS BOWRON / P. B. KERBER, op. cit., p.

${ }^{44}$ POMPEO BATONI, Sir Humphry Morice, 1761- 62, Oil on canvas, 117.5 x $172.8 \mathrm{~cm}$, Norton Conyers, North Yorkshire, Sir James and Lady Graham.

${ }^{45}$ See E. PETERS BOWRON, op. cit., p. 44.

${ }^{46}$ E. PETERS BOWRON / P. B. KERBER, op. cit., p. 
Compared to the standard Grand Tour portraiture of the younger gentlemen (fig. 1, 4, 5), Sir Morice is not flashily dressed in the Italian fashion but holds on to his traditional inconspicuous English taste in clothes. Although his three-piece-suit is not made of robust wool but of silk, it, nevertheless, is designed to be very practical for hunting; which is especially evident by his rolled up cuffs and the suit's dull grey colour made for leisure in nature. ${ }^{47}$ In a foreign country he sticks to his principles. Through his casual dress style and informal appearance, he bears eloquent testimony that he is a conservative English country gentleman.

\section{CONCLUSION}

In this study one sees that specific "rules" existed regarding depiction of the gentlemen, mostly aristocrats, on the Grand Tour. Nevertheless, in the large number of portraits produced from the middle to the end of the eighteenth century, we see subtle distinctions according to the tastes of the models. We also see the obsession with antiquity made clear not only by the ancient architecture and works of art shown in the portraits but by the appearance of the sitters. Their thin and well-proportioned silhouettes reflect the antique ideal of beauty observed in ancient sculptures.

Furthermore, the portraits show us that Grand Tour was a pleasant but nevertheless structured educational experience for the tourists. It was a kind of "finishing" education for them that gave them knowledge, social grace, and polish. Furthermore, the Grand Tour contributed to the great interest in the eighteenth century in things classical, which helped shape British society then in ways that remain with us today.

${ }^{47}$ See E. PETERS BOWRON, op. cit., p. 45. 


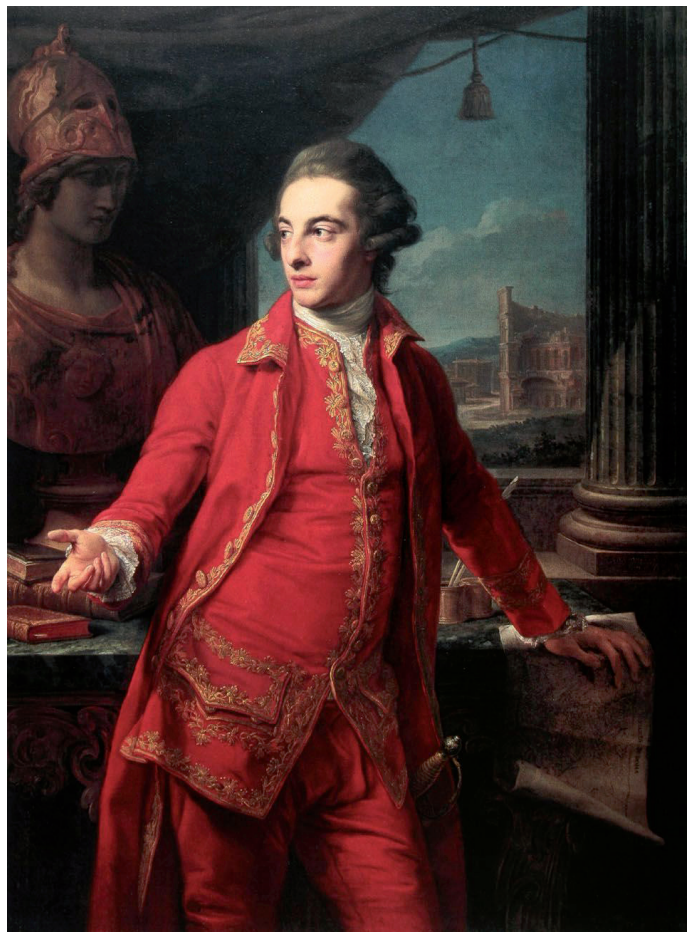

- Fig. 1. POMPEO BATONI:Sir Gregory Page-Turner, 1768, Oil on canvas, 134.5 x $99.5 \mathrm{~cm}$.

Fuente: Manchester, Manchester Art Gallery, inv. No. 1976.79. (Manchester City Galleries.)

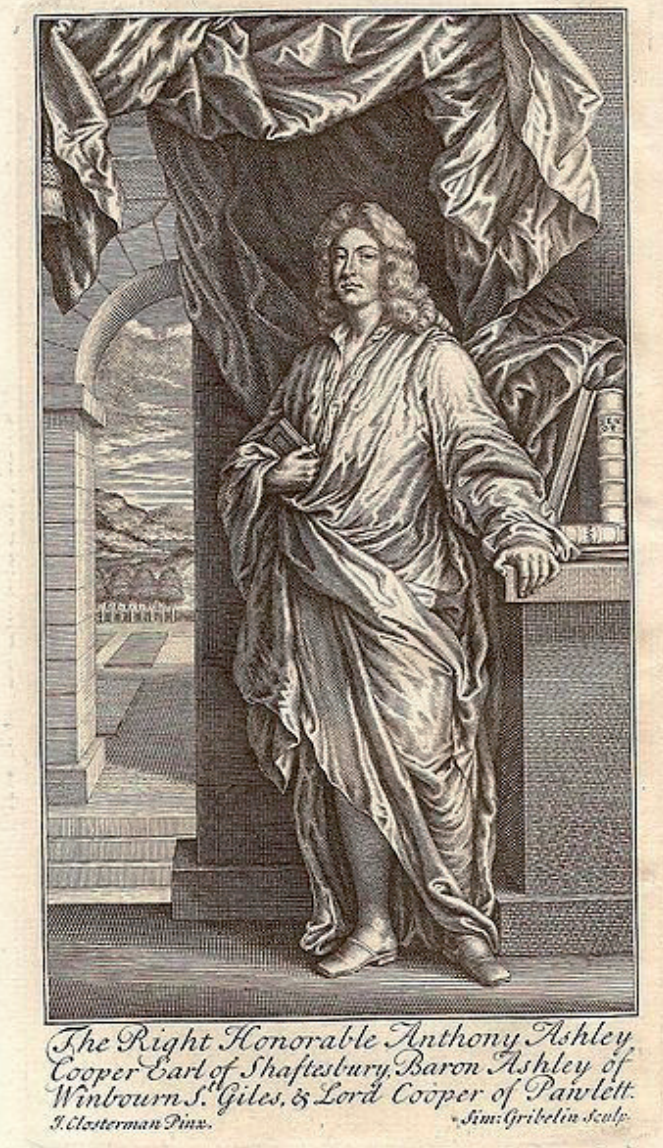

- Fig. 2. SIMON GRIBELIN AFTER JOHN CLOSTERMAN:Anthony Ashley-Cooper 3rd Earl of Shaftesbury, 1723, line engraving on paper, $179 \times 98 \mathrm{~mm}$.

Fuente: London, National Portrait Gallery, inv. no. NPG D 14157. (National Portrait Gallery, London.) 


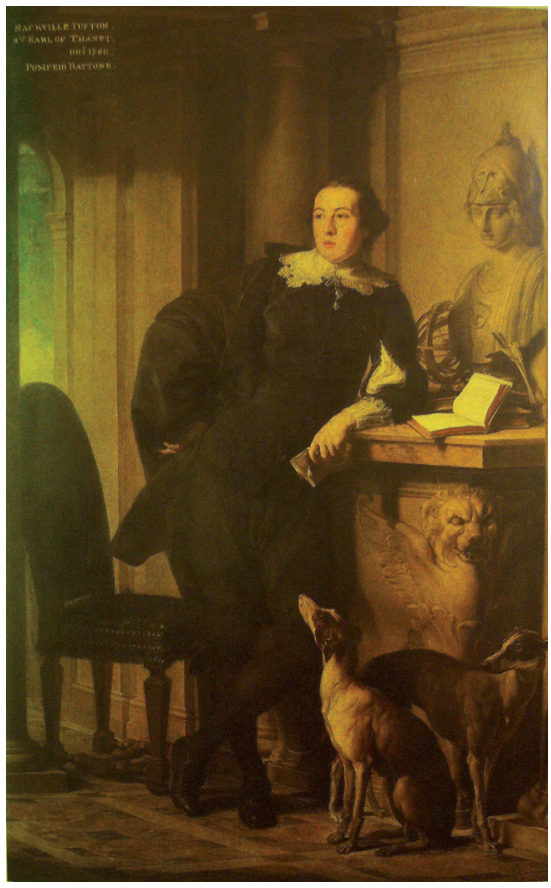

- Fig. 3. POMPEO BATONI, Sackville Tufton, 8th Earl of Thanet, 1753- 54, Oil on canvas, 233.7 x $147.3 \mathrm{~cm}$.

Fuente: Private Collection (Private Collection.)

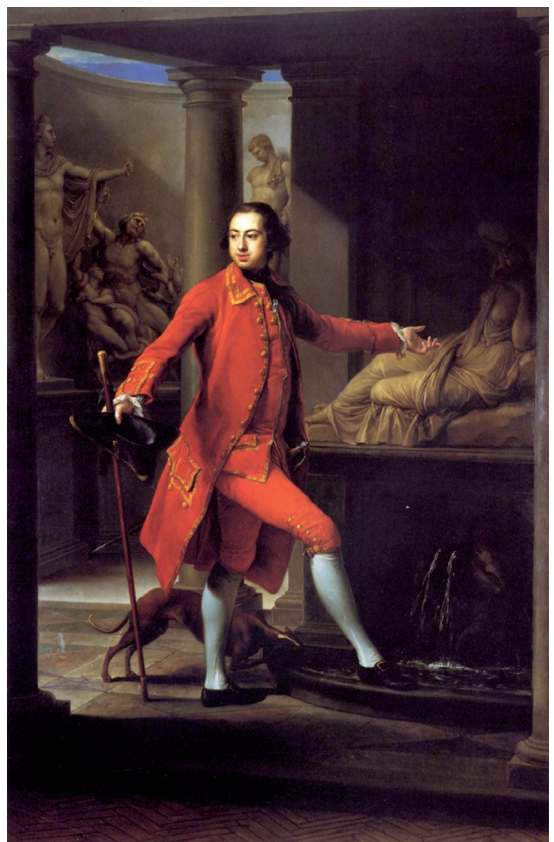

- Fig. 5. POMPEO BATONI:Thomas Dundas, later 1st Baron Dundas, 1764, Oil on canvas, 298 x $196.8 \mathrm{~cm}$.

Fuente: Property of Marquess of Zetland (Marquess of Zetland.)

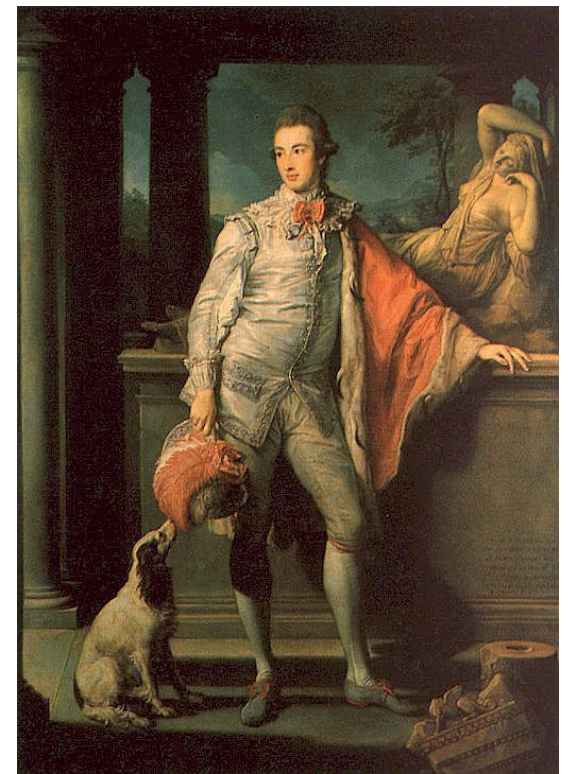

- Fig. 4. POMPEO BATONI: Thomas William Coke, later 1st Earl of Leicester, 1773- 74, Oil on canvas, $245.8 \times 170.3 \mathrm{~cm}$.

Fuente: Norfolk, The Earl of Leicester and the Trustees of the Holkham Estate (Collection of the Earl of Leicester, Holkham Hall, Norfolk:)

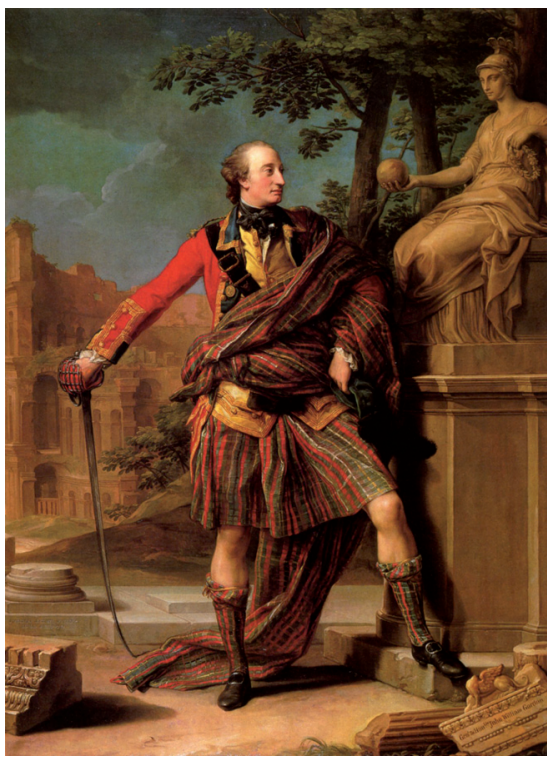

- Fig. 6. POMPEO BATONI, Colonel the Honorable William Gordon, 1765- 66, Oil on canvas, 259 x $187.5 \mathrm{~cm}$.

Fuente: Aberdeenshire, The National Trust for Scotland, Fyvie Castle (The National Trust for Scotland.). 


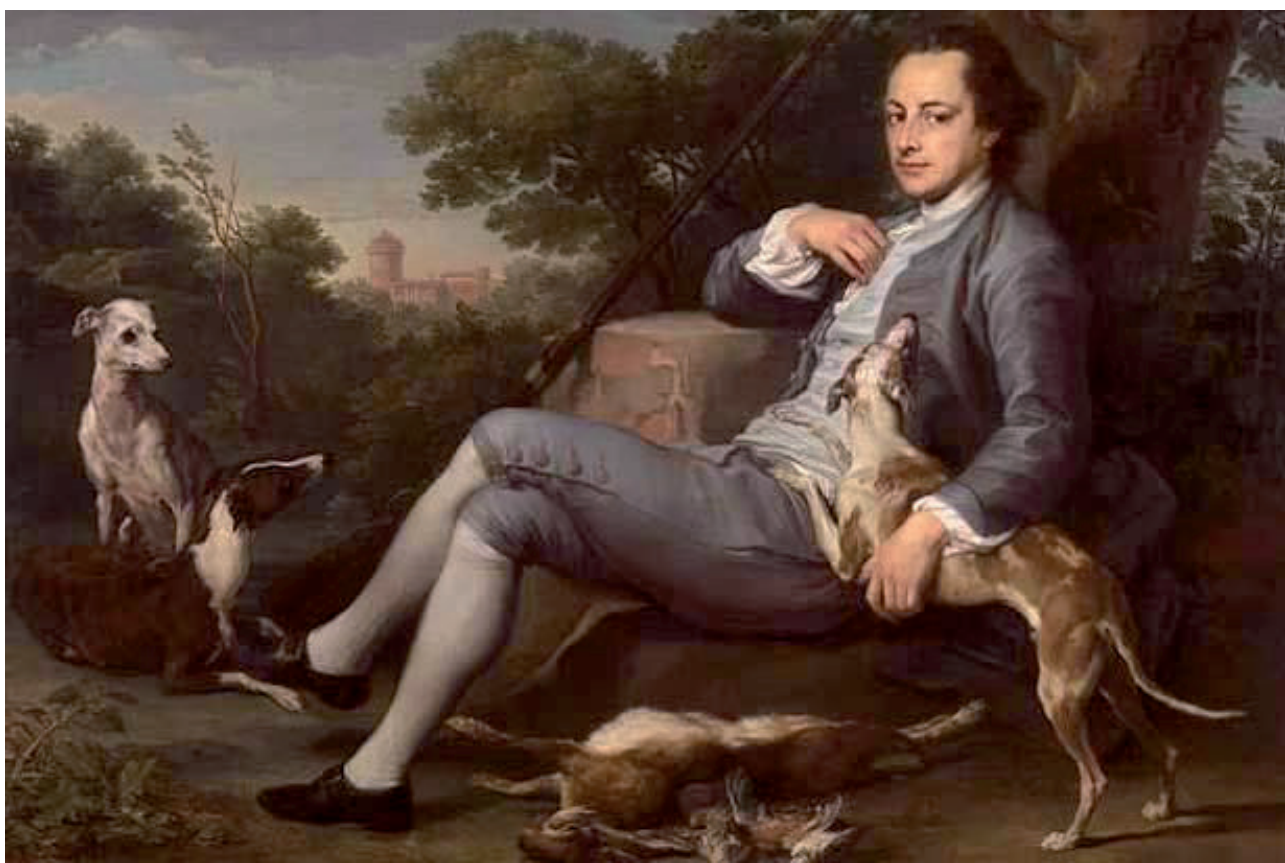

- Fig. 7. POMPEO BATONI, Sir Humphry Morice, 1761- 62, Oil on canvas, 117.5 x $172.8 \mathrm{~cm}$. Fuente: Norton Conyers, North Yorkshire, Sir James and Lady Graham (Private Collection.) 